\title{
İş Değerlerinin Demografik Özellikler Açısından İncelenmesi: Tekstil Çalışanları Üzerine Bir Araştırma
}

\author{
The Investigation of Work Values in Terms of Demographic Characteristics: A \\ Research on Textile Workers
}

\author{
Sefa ÇETIN* \\ Guzel SADYKOVA** \\ Aslihan SEÇER***
}

\begin{abstract}
$\ddot{O} Z$
$\dot{I}_{S ̧}$ değerleri, çalışanların iş süreçlerini algllama ve karar tercihlerini yönlendiren, işe yönelik inanç, tutum ve davranışlarını şekillendiren yargısal standartlardır. İş hayatında karşılaşılan durum ve uygulamaları "iyi veya kötü", "doğru veya yanlış" bağlamında irdelemek ve uygun davranış modelini benimsemek için zemin hazırlama işlevine sahiptirler. İş değerleri bilişsel, araçsal ve sosyal/duyuşsal değer boyutlarlyla temsil edilmiştir. Çalışmanın amacı, iş değerlerini demografik özellikler açısından incelemektir. Çalışmada iş değerlerinin cinsiyete, yaşa, mesleğe, deneyime ve ĕgitim düzeyine göre farklılaşma olasılı̆̆ sorgulanmıştır. Kastamonu'da faaliyette bulunan tekstil işletmesi çalışanları üzerinde uygulanan anketten elde edilen bulgular sonucunda iş değerlerinin demografik faktörlere göre değişmediği ortaya çıkmıştır.
\end{abstract}

\author{
ANAHTAR KELIMELER \\ İ̧s Değerleri; Bilişsel, Araçsal ve Duyuşsal Değerler; Demografik Özellikler; Çalışma Hayatı; Tekstil Çalışanları.
}

\begin{abstract}
Work values are judicial standards, guiding perception of employee's business processes and decision-making choices and shaping beliefs, attitudes and behaviors towards work. They have the function of preparing the ground to examine business life situations and applications in the context of "good or bad", "right or wrong" and to adopt appropriate behavior patterns. Work values were represented by cognitive, instrumental and affective value dimensions. The aim of the study is to examine the work values in terms of demographic characteristics. It was questioned probability of differentiation of work values by gender, age, occupation, experience and level of education. As a result of the findings obtained from the questionnaire applied on the textile enterprise employees in Kastamonu, it was found that the work values didn't change according to the demographic factors.
\end{abstract}

\section{KEYWORDS}

Work Values; Cognitive, Instrumental and Affective Values; Demographic Characteristics; Working Life; Textile Workers.

\begin{tabular}{|c|c|c|}
\hline \multicolumn{2}{|r|}{$\begin{array}{c}\text { Makale Geliş Tarihi / Submission Date } \\
\text { 13.11.2018 }\end{array}$} & $\begin{array}{c}\text { Makale Kabul Tarihi / Date of Acceptance } \\
02.01 .2019\end{array}$ \\
\hline Atuf & $\begin{array}{l}\text { Çetin, S., Sadykova, G., Seçer, A. (2 } \\
\text { Çalışanları Üzerine Bir Araştırma. Sels }\end{array}$ & $\begin{array}{l}\text { Demografik Özellikler Açısından İncelenmesi: Tekstil } \\
\text { Bilimler Meslek Yüksekokulu Dergisi, } 22 \text { (1), 66-73 }\end{array}$ \\
\hline
\end{tabular}

\footnotetext{
* Doç. Dr., Kastamonu Üniversitesi, İktisadi ve İdari Bilimler Fakültesi, Siyaset Bilimi ve Kamu Yönetimi Bölümü, sefacetin@kastamonu.edu.tr, ORCID: 0000-0003-0935-5097

** Dr. Öğr. Üyesi, Kastamonu Üniversitesi, İktisadi ve İdari Bilimler Fakültesi, İşletme Bölümü, gsadykova@ kastamonu.edu.tr, ORCID : 0000-0002-9996-5835

${ }_{* * * *}^{*}$ Yüksek Lisans Öğrencisi, Kastamonu Üniversitesi, Sosyal Bilimler Enstitüsü, aslihansecer37@ gmail.com, ORCID :0000-0001-5526-2727
} 


\section{GíRiş}

Günümüzde işletmelerin başarısı çoğunlukla beşeri sermaye, hizmet kalitesi, müşteri memnuniyeti vb. finansal olmayan kriterlere bağlıdır. Bu nedenle insan kaynağı öncelikli olarak yatırım yapılması ve elde tutulması gereken bir değer olarak ortaya çıkar (Baysal ve İnceoğlu, 2016). Çalışanların öznel hedefleri ile örgütsel amaçları uyumlaştırma, onları motive etme, örgüte yönelik bağlılık, sadakat duygularını pekiştirme, ortak kültür anlayışını benimsetme, benzer değerlerle güdülenmeye yöneltme vb. aracılığıyla gerçekleşir. İşletmede çalışanların işe yönelik tutum, inanç ve değerlerini şekillendirme adına ortak bir bilinç oluşturma stratejileri örgüt kültürü çerçevesinde güncellik kazanır. Bu bağlamda işletme içerisinde çalışanların güdülenme mekanizmalarını anlama, çalışma ortamında gelişebilecek olaylara karşı tepkilerini tahmin edebilme, çalışanları benzerlik ilkesine göre gruplandırarak etkileme, iş süreçlerinin bireysel algılanması ve karar verme açısından araçsallaştırılması zorunluluğu, iş değerleri konusunda demografik özelliklerin fark ve niteliklerini belirlemenin önemini ön plana çıkarır.

İş değerleri, işletmenin kendisine özgü var olma felsefesini yansitan örgüt kültürünün temel bileşeni olup, çalışanlara işletmedeki görevleri, karşılığında edindikleri maddi bedele verdikleri anlam, işletme içerisindeki davranış standartları ve etkileşim kurma ölçüleri konularında rehberlik eden yargıları içerir.

Çalışma iş değerlerini demografik özellikleri açısından incelemeyi amaçlamaktadır. İlgili amaç doğrultusunda iş değerlerinin kavramsal altyapısı, demografik özelliklerle olan ilişkisi açıklanmış; iş değerlerinin bilişsel, araçsal ve sosyal boyutları çerçevesinde geliştirilen anket aracılığıyla Kastamonu'da faaliyette bulunan tekstil işletmesi çalışanlarından elde edilen veriler temelinde iş değerlerinin demografik özellikler açısından farklılaşma potansiyeli ortaya konmuştur.

\section{KAVRAMSAL ÇERÇEVE}

\section{1. İş Değerleri}

İş değerleri, değerlerin bir alt kümesi olup, bireyin işyerinden sağlamak istediği özel bir sonuca verdiği önem derecesi şeklinde tanımlanabilir (Sagie ve diğg, 1996; Kubat ve Kuruüzüm, 2010). İşin belirli niteliklerine (ücret, özerklik, çalışma şartları vb.) ve iş ile ilgili sonuçlara (başarı, tatmin, prestij vb.) ilişkin genel inançları içerir (Bağrıyanık, 2016: 70).

Çalışma yaşamının merkezinde yer alan iş değerleri, insanların mesleklerinde, işlerinde ve örgütlerinde sahip oldukları iş yaşamlarının anlamını ifade eder (Bayar, 2016: 40). İş değerleri işgörenin, çalışmadan ne beklediği ve nasıl davranmak zorunda olduğu hakkındaki bireysel görüşünü yansıtır (Baysal ve İnceoğlu, 2016: 133). İş değerleri, bireyin çalıştığı işin türü ve iş ortamı ile ilgili beklenti, ihtiyaç, hedef ve tutumlarını şekillendirir (Wanous ve diğ., 1983: 66; Sığrı, 2007); çalışanlara, iş ortamında karşılaşılan durumlar ve uygulamalar karşısında, "iyi veya kötü”, "doğru veya yanlış" gibi yargılara varmasında kriter teşkil ederler (Weihrich ve Koontz, 1993; Dose, 1997; Sığr1, 2007; Özkan ve Gümüş, 2013).

İlgili alanyazında iş değerlerinin içsel ve dışsal olmak üzere sınıflandırılması yaygın bir görüş olarak ortaya çıkar (Super, 1970; Zytowski, 1994; Jiang ve Yang, 2011; Kubat ve Kuruüzüm, 2010; Bayar, 2016). İçsel değerler, özgecilik (fedakârlık), yaratıcılık, zihinsel teşvik, başarı, bağımsızlık vb. işin içeriğine ilişkin ve işe ait süreçlerle ilgili değerleri yansıtır. Dışsal değerler, işin içeriğinden bağımsız olup, işin çıktıları ve sonuçları ile ilgili olan ekonomik fayda, güvenlik, çevre, üstlerle ilişkiler, çalışma arkadaşları, prestij ve yaşam tarzını ifade eder (George ve Jones, 1997; Dagenais, 1998; Bayar, 2016). Örücü ve arkadaşları (2003) çalışanların iş değerlerini; parasal değerler, sosyal güvenlik, sosyal gereksinimler, değer görme, saygı, statü, kendini gerçekleştirme, çalışma ortamı, işin özellikleri şeklinde boyutlandırmışlardır (Avcı, 2011: 8).

Elizur ve arkadaşları (1991) iş değerlerini araçsal, bilişsel ve sosyal/duyuşsal olmak üzere üç kategoride değerlendirmişlerdir. Araçsal değerler, maaş, yıllık izin ve hastalık izni, sigorta, iş güvenliği, kalıcı iş, uygun çalışma saatleri, çalışma koşulları gibi maddi getiri veya sonuçları içerir. Bilişsel değerler, ilgi, başarı, kişisel gelişim, sosyal sorumluluk, terfi imkanları, işin sonuçlarına iliş̧in geribildirim, iş merakı, ilginç olan işi yapma, anlamlı iş, yetenek ve bilgi kullanımı, işyerinde bağımsızlık vb. kapsar. Sosyal/duyuşsal değerler kişilerarası ilişkilerle ilgilenir, iş arkadaşları, yönetici ile olan etkileşim, bireysel değer görme, insanlarla tanışma ve onlarla etkileşim kurma firsatı, adil ve saygılı bir yöneticiye sahip olma vb. etkenleri öngörür.

\section{2. İş Değerleri ile Demografik Özellikler Arasındaki İlişki}

İlgili alanyazında iş değerleri ile demografik özellikler (cinsiyet, yaş, meslek, eğitim, deneyim) arasındaki ilişkinin niteliğini betimleyen çalışmalardan elde edilen sonuçlar değişkenlik arz etmektedir.

Cinsiyet bağlamında yapılan araştırmalarda ağırlıklı olarak erkeklerin ücret, kariyer, prestij ve terfi imkanlarına odaklı olduklarını, kadınların ise iş ortamı, çalışma arkadaşları arasındaki etkileşimleri ön planda 
tuttukları saptanmıştır (Konrad ve diğ., 2000; Ergeneli ve Temirbekova, 2006; Li ve diğ., 2008; Kubat ve Kuruüzüm, 2010). Bunun yanı sıra bazı araştırmalarda cinsiyetin iş değerlerini değiştirmediği, kadın ve erkeklerin iş değerleri arasında fark olmadığı belirlenmiştir (Chen, 1995; Rowe ve Snizek, 1995; Cheung ve Scherling, 1999; Kaya, 2010). Yaş unsuru temelinde yapılmış araştırmalar farklı yaş gruplarının iş değerleri açısından büyük oranda farklılıklar gösterebileceği yönündedir (Buchholz, 1978; Fundenburg, 1996; Uyan, 2002). Meslek ve iş değerleri etkileşimlerini inceleyen araştırmalarda özel sektör çalışanlarının ücret ve terfi olanaklarına daha fazla değer verdikleri (Kasnak, 1998), farklı meslek gruplarının iş değerleri açısından önemli farklılıklarının bulunmadı̆̆ı tespit edilmiştir (Shapira ve Griffith, 1990; Akıner ve diğ, 2005; Kubat ve Kuruüzüm, 2010). Deneyimli çalışanların işletmenin itibarına ve güvenliğe, araçsal ve bilişsel değerlere önem verdikleri ortaya çıkmıştır (Jurgensen, 1978; Kubat ve Kuruüzüm, 2010). Eğitim ve iş değerleri etkileşimi bağlamında üniversite mezunlarının işe yönelik beklentilerinin yüksek olduğu, bilişsel ve araçsal değerlere önem verdikleri; lise mezunlarının daha fazla araçsal ve sosyal değerlerle güdülendikleri belirlenmiştir (Kasnak, 1998; Kuvan, 2007; Kubat ve Kuruüzüm, 2010).

Dolayısıyla, iş değerlerinin sınıflandırmalarının temelinde işe yüklenen ekonomik anlam, çalışanların ait olma, değer ve kendini gerçekleştirme gereksinimleri, işin gerçekleştirilmesinden duyulan tatmin, profesyonel gelişim ve yükselme özleminin yattığı görülmektedir.

\section{YÖNTEM}

\subsection{Araştırmanın Amacı ve Önemi}

Çalışmanın amacı, iş değerlerini yaş, cinsiyet, eğitim, deneyim ve meslek gibi demografik özellikler açısından irdelemek, demografik özelliklerin iş değerlerini ne derece etkilediğini, farklılık olasılıklarını sorgulamaktır. İş değerlerinin demografik özellikler açısından incelenmesi, çalışanların işe yönelik inanç, tutum ve değerlerinin, bireysel ve örgütsel amaçları uyumlaştırmaya zemin sağlayacak operasyonel altyapıyı oluşturma ve güdüleme araçları konusunda bilinçlenme yönünden kullanılabilirliklerini ortaya koyma açısından önem arz etmektedir.

\subsection{Araştırmanın Evreni, Örneklemi ve Sınırılıkları}

Araştırmanın evrenini Kastamonu'da faaliyet gösteren bir tekstil işletmesinde istihdam edilen 309 çalışan oluşturmaktadır. İlgili işletmede istihdam edilen İşKUR çalışanları, makinacılar, ortacılar, ustabaşları, araştırmanın örneklemidir. Kurumun sekreterleri, muhasebeciler, yemekhane çalışanları, güvenlik görevlileri araştırmaya dahil edilmeyen 59 kişi arasındadırlar. Dolayısıyla, 250 çalışana anket uygulanmış olup, 217 katılımcıdan geri dönüş sağlanmıştır. Araştırma belirlenmiş örneklem, ankette yer alan ölçeğin soruları ve araştırmanın hipotezleri ile sınırlıdır.

\subsection{Araştırmanın Kapsamı ve Yöntemi}

Veri edinme aracı olarak iki bölümden oluşan anket yöntemi kullanılmıştır. Anketin ilk bölümünde çalışanların demografik özelliklerini belirlemeye yönelik 8 soruya yer verilmiştir. İş değerleri Selmer ve Waldstrøm (2007)'un çalışmasından alınarak Türkay ve Akgöz (2016) tarafindan Türkçe'ye uyarlanmış olan Elizur, Borg, Hunt ve Magyari-Beck'in (1991) sosyal/duyuşsal, bilişsel ve araçsal boyutlarını tanımlayan 23 maddelik iş değerleri ölçeğiyle ölçülmüştür. Ölçeğin orijinalinde soru sayısı 24 olup, içerik benzerliğinden dolay1 2 soru birleştirilerek 23 maddelik bir ölçek haline getirilmiştir. İş değerleri ölçeğinin güvenilirlik ve geçerlilik analizleri yapılmıştır. Ölçeğin Cronbach Alfa katsayısı, 0,915'tir. İş değerleri ölçeği boyutlarının Cronbach Alfa katsayıları bilişsel iş değerleri boyutu için 0,855 , sosyal iş değerleri için 0,791 , araçsal iş değerleri için 0,818 'dir. Ölçeğin bilişsel iş değerleri boyutu maddelerinin faktör yükleri aşağıdaki gibidir: $\mathrm{B} 1=0,560 ; \mathrm{B} 2=0,583 ; \mathrm{B} 3=0,467 ; \mathrm{B} 4=0,644 ; \mathrm{B} 5=0,509 ; \mathrm{B} 6=0641 ; \mathrm{B} 7=0,688 ; \mathrm{B} 8=0,653 ; \mathrm{B} 9=0,496$; $\mathrm{B} 10=0,575 ; \mathrm{B} 11=0,394 ; \mathrm{B} 12=0,677 ; \mathrm{B} 13=0,343$. Sosyal iş değerleri boyutu maddeleri için faktör yükleri, $\mathrm{S} 1=0,526 ; \mathrm{S} 2=0,587 ; \mathrm{S} 3=0,546 ; \mathrm{S} 4=0,554 ; \mathrm{S} 5=0,666$ şeklindedir. Araçsal iş değerleri boyutu maddelerinin faktör yükleri, A1 $=0,625 ; \mathrm{A} 2=0,589$; $\mathrm{A} 3=0,554 ; \mathrm{A} 4=0,445$ ve A5 $=0,540$ 'tır. İlgili alanyazında bir maddenin faktör yük değerinin en az 0,30 olması gerektiği ve 0,30 değerinden yüksek olan maddelerin ölçekte tutulabileceği görüşü savunulmaktadır (Kline, 1998; Pehlivan, 2012; DeVellis, 2014; Büyüköztürk, Şekercioğlu ve Çokluk, 2018).

İş değerleri ölçeğinin faktör yapıları (özdeğer ve varyans yüzdeleri) Tablo 1'de verilmiştir. 
Tablo 1:İş Değerleri Ölçeğinin Faktör Yapıları

\begin{tabular}{|l|c|c|c|}
\hline \multicolumn{1}{|c|}{ Faktör } & Özdeğer & Varyans Yüzdesi & Toplam Varyans Yüzdesi \\
\hline Faktör 1 - Bilişsel İs Değerleri & 8,401 & 36,525 & 36,525 \\
\hline Faktör 2 - Sosyal İș Değerleri & 1,947 & 8,466 & 44,991 \\
\hline Faktör 3 - Araçsal İș Değerleri & 1,348 & 5,861 & 50,852 \\
\hline
\end{tabular}

Tablo 1 incelendiğinde, iş değerleri ölçeği faktörlerinin toplam varyansa yaptıkları katkı, bilişsel iş değerleri faktörü için $\% 36,5$, sosyal iş değerleri faktörü için $\% 8,5$, araçsal iş değerleri faktörü için ise $\% 5,9$ 'dur. Söz konusu faktörlerin varyansa yaptıkları toplam katkının \%50,9 olduğu görülmektedir. Sosyal bilimlerde yapılan analizlerde $\% 40$ ile $\% 60$ arasında değişen varyans oranları yeterli kabul edilmektedir (Scherer ve diğ., 1988; Tavşanc11, 2014; Büyüköztürk, Şekercioğlu ve Çokluk, 2018). KMO analizi sonucu, 0,910 olup, Bartlett testi anlamlı $(\mathrm{p}=, 000)$ olarak saptanmıştır.

İş değerleri ölçeğinde 5'li Likert tipi ölçeklendirme (1-Kesinlikle Katılmıyorum, 2-Katılmıyorum, 3Kararsızım, 4-Katılıyorum, 5-Kesinlikle Katılıyorum) kullanılmıştır. Verilerin analizi SPSS 20 programıla gerçekleştirilmiş ve analiz esnasında yüzde, frekans, tek yönlü Anova, T testi analizlerinden yararlanılmıştır.

\subsection{Araştırmanın Hipotezleri}

İş değerlerinin demografik özellikler açısından incelendiği uygulamalı çalışmada aşağıdaki hipotezler geliştirilmiştir:

H1: Çalışanların iş değerleri cinsiyetlerine göre farklı1ık gösterir.

H2: Çalışanların iş değerleri yaş gruplarına göre farklılık gösterir.

H3: Çalışanların iş değerleri eğitim seviyelerine göre farklılık gösterir.

H4: Çalı̧̧anların iş değerleri mesleklerine göre farklılık gösterir.

H5: Çalışanların iş değerleri deneyimlerine göre farklılık gösterir.

\section{ARAŞTIRMANIN BULGULARI VE YORUMU}

Katılımcıların demografik bilgileri Tablo 2'de sunulmuştur.

\section{Tablo 2:Katılımcıların Demografik Özellikleri}

\begin{tabular}{|c|c|c|c|c|c|}
\hline Cinsiyet & $\mathbf{F}$ & $\%$ & Kurumda Çalıșma Süreleri & $\mathbf{F}$ & $\%$ \\
\hline Bayan & 145 & 66,8 & $1-5$ Ay & 60 & 27,6 \\
\hline Erkek & 72 & 33,2 & 6-11 Ay & 50 & 23,0 \\
\hline Yaş & & & 1-5 Y11 & 73 & 33,6 \\
\hline $18-23$ & 26 & 12,0 & 5-10 Y11 & 34 & 15,7 \\
\hline $24-29$ & 62 & 28,6 & Maaş & & \\
\hline $30-35$ & 50 & 23,0 & 1300’ den $\mathrm{Az}$ & 30 & 13,8 \\
\hline $36-41$ & 50 & 23,0 & $1300-1800$ & 182 & 83,9 \\
\hline $42-47$ & 21 & 9,7 & $1900-2400$ & 5 & 2,3 \\
\hline 50 ve Üzeri & 8 & 3,7 & $2500-3000$ & - & \\
\hline Ĕgitim & & & 3000 ve Üzeri & - & \\
\hline İlkokul & 65 & 30,0 & Çalıştıkları İş Yeri Sayısı & & \\
\hline Ortaokul & 68 & 31,3 & 1 ile 3 Aras 1 & 158 & 72,8 \\
\hline Lise & 66 & 30,4 & 4 ile 6 Aras 1 & 44 & 20,3 \\
\hline Önlisans & 11 & 5,1 & 7 ile 9 Aras 1 & 9 & 4,1 \\
\hline Lisans & 7 & 3,2 & 9 ve Daha Fazla & 6 & 2,8 \\
\hline Meslek & & & İstihdam edildikleri meslek sayısı & & \\
\hline Ustabaşı & 8 & 3,7 & 1 ile 3 Aras 1 & 176 & 81,1 \\
\hline Çalışanlar & 207 & 95,4 & 4 ile 6 Aras 1 & 27 & 12,4 \\
\hline Diğer & 2 & 0,9 & 7 ile 9 Aras1 & 6 & 2,8 \\
\hline & & & 9 ve Daha Fazla & 8 & 3,7 \\
\hline
\end{tabular}

Tablo 2'deki verilere göre, katılımcıların \%66,8'i bayan, \%62'si 24-29 arası yaş grubu aralığındadır. Çalışanların eğitim düzeyleri dikkate alındığında, \%68'lik oranla ortaokul mezunları oldukları görülmektedir. Araştırmaya 207 çalışan, 8 ustabaşı, 1 insan kaynakları sorumlusu ve 1 sosyal sorumluluk ve denetim uzmanı katılmıştır. Kurumdaki çalışma sürelerine bakıldığında, en fazla katılım \%33,6'lık oranla 1-5 yıl arası 
deneyime sahip çalışanlar tarafından sağlanmıştır. Çalışanların \%83,9'u 1300-1800 TL arası bir maaş almakta, ustabaşları için ücret 1900-2400 TL aralığında değişmektedir. İŞKUR çalışanları, 1300 TL'den az ücret alanlar kategorisindedirler. Katılımcıların \% 72,8'inin en az 1, en fazla 3 işyerinde çalıştıkları, \%81,1 oranla ise en az 1, en fazla 3 farklı meslek alanlarında istihdam edildikleri görülmektedir.

İş değerlerine yönelik verilen cevapların standart sapma ve ortalama değerleri Tablo 3 'te yer almaktadır.

Tablo 3:Katılımcıların İş Değerleri ile İlgili Yanıtlarının Standart Sapma ve Ortalama Değerleri

\begin{tabular}{|l|c|c|}
\hline \multicolumn{1}{|c|}{ Bilişsel Değerler } & Ort. & St. Sapma \\
\hline İşimde ilerleyebiliyorum, terfi (yükselme) imkanım vardır. & 2,92 & 1,45 \\
\hline Çalışmamın sonuçları ile ilgili olarak geribildirim alıyorum. & 3,08 & 1,29 \\
\hline İşyerinde statüm (bulunduğum konumum) belirlidir. & 3,50 & 1,32 \\
\hline İşimin başında başarılıyımdır. & 4,04 & 1,14 \\
\hline İlgi alanım, bana ilginç gelen işleri yapmaktır. & 3,05 & 1,46 \\
\hline Anlamlı bir iş yaptığımı düşünüyorum. & 3,79 & 1,20 \\
\hline İşimde kişisel gelişimim için elde edebileceğim fırsatlar vardır. & 3,31 & 1,34 \\
\hline Yetenek ve bilgimi işimde kullanabilme imkanım vardır. & 3,61 & 1,26 \\
\hline İşimle ilgili sorumluluk verilir. & 4,02 & 1,00 \\
\hline İşimde bağımsız çalışabiliyorum. & 3,07 & 1,44 \\
\hline Yaptı̆ı̆ım iş ile toplumsal katkı üretiyorum. & 3,79 & 1,12 \\
\hline Kurumum, çalışıyor olmaktan gurur duyduğum bir kurumdur. & 3,84 & 1,22 \\
\hline Kurumumda ve işimde güç sahibi/etkili olmak istiyorum. & 3,64 & 1,23 \\
\hline \multicolumn{1}{|c|}{ Sosyal/Duyuşsal Değerler } & & \\
\hline İșimi iyi yaptı̆ğımda takdir edilirim. & 3,58 & 1,26 \\
\hline İş arkadaşlarım naziktir, herkesle geçinirler. & 3,36 & 1,31 \\
\hline Kurumumda bir itibarım vardır, adam gibi değer görürüm. & 3,26 & 1,33 \\
\hline İnsanlarla tanışma ve etkileşim kurma firsatım vardır. & 3,85 & 1,06 \\
\hline Yöneticimiz, adil ve çok düşünceli bir patrondur. & 3,76 & 1,31 \\
\hline \multicolumn{1}{|c|}{ Araçsal Değerler } & & \\
\hline Aylık gelirim, elde ettiğim bir tutar vardır. & 4,00 & 1,05 \\
\hline $\begin{array}{l}\text { Ek kazançlar, tatiller, hastalık izni, sosyal yardımlar, sigorta vb. } \\
\text { imkanlarımız vardır. }\end{array}$ & 3,91 & 1,16 \\
\hline İş güvenliğimiz ve daimi bir işimiz vardır. & 3,99 & 1,04 \\
\hline Çalışsma saatleri bana uygundur. & 3,80 & 1,16 \\
\hline İşşrtlarımız rahat ve temizdir. & 3,67 & 1,24 \\
\hline & & \\
\hline
\end{tabular}

Tablo 3'teki aritmetik ortalamalara bakıldığında, bilişsel değerlerde iş başında başarılı olmanın $(4,04)$ ve işle ile ilgili sorumluluğun $(4,02)$; sosyal/duyuşsal değerlerde insanlarla tanışma ve etkileşim kurma firsatının $(3,85)$; araçsal değerlerde aylık gelirin, elde edilen tutarın $(4,00)$ ön plana çıktığı görülmektedir.

İş değerlerinin çalışanların cinsiyetlerine göre farklılık gösterip göstermediğini belirlemek için $T$ testi uygulanmıştır. T testi sonuçları Tablo 4'te verilmiştir.

Tablo 4:Cinsiyete Göre İş Değerleri Algısı Farklılığı

\begin{tabular}{|l|c|c|c|c|c|}
\hline & $\mathbf{N}$ & Ortalama & St. Sapma & T & P \\
\hline Bayan & 145 & 3,59 & 0,70 & -219 & 0,827 \\
\cline { 1 - 4 } Erkek & 72 & 3,62 & 0,78 & & \\
\hline
\end{tabular}

Tablo 4'teki verilere göre, $\mathrm{p}$ değeri, 0,827 'dir ve $0,827>0,05$ olduğu için çalışanların iş değerlerinin cinsiyetlerine göre farklı1ık göstermediği sonucuna ulaşılmıştır. Dolayısıyla, H1 doğrulanmamıştır.

H2, H3, H4, H5 tek yönlü Anova ile test edilmiştir. Değişkenlerin tek yönlü Anova testi sonuçları Tablo 5 'te sunulmuştur. 
Tablo 5:Tek Yönlü Anova Testi Sonuçları

\begin{tabular}{|c|c|c|l|}
\hline Değişkenler & F & P & \multicolumn{1}{|c|}{ Açılklama ( \%5 Anlamlılık Düzeyi ) } \\
\hline H2 & 0,49 & 0,782 & $\begin{array}{l}0,782>0,05, \text { çalışanların iş değerleri yaş } \\
\text { gruplarına göre farkl11ık göstermez. }\end{array}$ \\
\hline H3 & 1,28 & 0,278 & $\begin{array}{l}0,278>0,05, \text { çalışanların iş değerleri eğitim } \\
\text { seviyelerine göre farkl1lk göstermez. }\end{array}$ \\
\hline H4 & 1,60 & 0,203 & $\begin{array}{l}0,203>0,05, \text { çalışanların iş değerleri } \\
\text { mesleklerine göre farklılık göstermez. }\end{array}$ \\
\hline H5 & 1,09 & 0,351 & $\begin{array}{l}0,351>0,05, \text { çalışanların iş değerleri } \\
\text { deneyimlerine göre farkl1lk göstermez. }\end{array}$ \\
\hline
\end{tabular}

Tablo 5 incelendiğinde, çalışanların yaş, eğitim, meslek ve deneyimlerine göre iş değerlerinin farklılık göstermediği görülmektedir. H1 gibi, geri kalan hipotezler de doğrulanmamıştır.

\section{SONUÇ VE DEĞERLENDİRME}

İş değerleri, çalışanların işlerinin devamlılığını sürdürme konusundaki gönüllülük kararlarının temelinde yatan ve işe ilişkin davranış kalıplarını benimseten inanç ve yargılardır. İlgili değerler ekonomik getiri sağlamanın yanı sıra çalışanlar açısından iş ortamında gerçekleşenleri anlamlı bulma, kendilerini dış dünyaya karşı konumlandırma, öznelliklerini bulundukları çevreye yansıtabilme işlevlerini yerini getirir. Çalışmada iş ortamını yorumlamanın cinsiyet başta olmak üzere yaş, meslek, deneyim ve eğitim gibi demografik etkenlere bağlı olarak değişkenlik gösterip göstermediği sorgulanmıştır.

Araştırmanın bulguları iş değerlerinin cinsiyet, yaş, eğitim, meslek ve deneyim gibi demografik özelliklere göre farkl1lık göstermediğini ortaya koymuştur. İş değerleri örgüt kültürünün sürekli olarak gelişen ve yenilenen bileşeni olup, işletme içerisinde öğrenilen çözümler, ortak misyonun benimsetilmesi ve çalışanlara örgütsel kimlik kazandırılması açısından zorunlu bir etkendir. Örgütsel kimlik, işletme içerisinde doğru kabul edilen değerlerin sosyalizasyon süreçleri temelinde paylaşılmasını ve yeni katılan çalışanlara aktarılmasını öngörür. Bu nedenle bir işletme içerisinde demografik özelliklerden bağımsız olarak benzer ya da özdeş iş değerlerine sahip çalışanların bulunması, o işletmenin etkin bir örgüt kültürüne sahip olduğuna işaret eder.

Araştırma katılımcıların demografik özelliklerden bağımsız bir şekilde araçsal değerlere daha fazla önem verdiklerini bulgulamıştır. Araçsal değerler tatmin edici ekonomik sonuçların, iş güvenliğinin, ergonomik çalışma ortamının, uygun çalışma saatlerinin, sigorta, izin ve ek kazanç elde etme imkanlarının bulunmasını amaçlar. Dolayısıyla, çalışanların ihtiyaç ve isteklerini karşılamaya yönelik bulundukları ekonomik faaliyetlerin anlamını oluşturan iş motivasyonunun ekonomik araçlarını içerir. İşletmenin verimliliği ve iş performansı öncelikli olarak çalışanları iş konusunda güdüleyen ekonomik ve psikososyal araçların farkında olunması, beklentilere uygun ve bütünlük içerisinde kullanılması ile sağlanır.

İş değerlerinin örgüt kültürü, iş - yaşam dengesi, iş motivasyonu, iş performansı, işyeri maneviyatı, sosyal zeka, öğrenilmiş güçlülük, kişisel gelişim yönelimi, bilgi paylaşma davranışları, yönetsel etkililik, personel güçlendirme vb. faktörlerle etkileşimleri bağlamında farklı ölçek ve örneklem içerisinde incelenmeleri, hem bireysel karar ve tercihleri anlama, hem de örgütsel amaçları çalışanlara benimsetme stratejilerini kavrama açısından fayda sağlayacaktır. 


\section{KAYNAKÇA}

Akıner, İ., Esin, N. ve Giritli, H. (2005) “Türk İnşaat Endüstrisinde İş Değerleriyle İlgili Kültürel Profil” İTÜ Dergisi/A, Mimarlık, Planlama, Tasarım 4(2), s. 47-58.

Avc1, N. (2011) "Turizm Eğitimi Alan Lisans Öğrencilerinin İş Değerleri: Çeşme Turizm ve Otelcilik Yüksekokulu Örneği” Anatolia: Turizm Araştırmaları Dergisi 22(1), s. 7-18.

Bağrnyanık, H. (2016) "Öğretmenlerin İş Değerleri ile Örgütsel Bağl1lık Düzeyleri Arasındaki İlişki” Türk Eğitim Bilimleri Dergisi 14(1), s. 69-84.

Bayar, L.S. (2016) "Demografik Faktörlerin İş Değerleri Üzerine Etkisi: İş̧̧i Sendikaları Üzerine Bir Araştırma" Adnan Menderes Üniversitesi Sosyal Bilimler Enstitüsü Dergisi 3(1), s. 37-67.

Baysal, H. ve İnceoğlu, E. (2016) "İş Değerleri Çerçevesinden Örgütsel Bağlılığa Bakış: Banka Çalışanlarına Yönelik Nitel Bir Araştırma” AİBÜ Sosyal Bilimler Enstitüsü Dergisi 16(3), s. 131-148.

Buchholz, R. (1978) “An Empirical Study of Contemporary Beliefs About Work in American Society" Journal of Applied Psychology 63(2), s. 219-227.

Büyüköztürk, Ş., Şekercioğlu, G., Çokluk, Ö. (2018) Sosyal Bilimler İçin Çok Değiş̧kenli İstatistik: SPSS ve LISREL Uygulamaları, Pegem Akademi Yayıncılık, Ankara.

Chen, I. (1995) "Work Values, Acculturation and Job Satisfaction Among Chinese Immigrant Professionals", Ph. D. Dissertation, New York University, New York.

Cheung, C.K. ve Scherling, S.A. (1999) "Job Satisfaction, Work Values, and Sex Differences in Taiwan's Organizations" Journal of Psychology: Interdisciplinary and Applied 133(5), s. 563-575.

Dagenais, F. (1998) "Super's Work Values Inventory Scales as Intrinsic or Extrinsic Constructs" Psychological Reports 83(1), s. 197-198.

DeVellis, R.F. (2014) Ölçek Geliştirme. Kuram ve Uygulamalar, çev. ed. Tarık Totan, Nobel Akademik, Ankara.

Dose, J.J. (1997) "Work Values: an Integrative Framework and Illustrative Application to Organizational Socialization" Journal of Occupational and Organizational Psychology 70(3), s. 219-240.

Elizur, D., Borg, I., Hunt, R. ve Magyari-Beck, I. (1991) “The Structure of Work Values: A Cross-Cultural Comparison” Journal of Organizational Behavior 12, s. 21-38.

Ergeneli, A. ve Temirbekova, J. (2006) "Ülkelere Göre İşe İlişkin Değerlerin İncelenmesi: Tekstil Sektöründe Kazak, Rus ve Türk Çalışanlarına Yönelik Bir Araştırma" Gazi Üniversitesi İktisadi ve İdari Bilimler Fakültesi Dergisi 7(2), s.121-143.

Fundenburg, D.L. (1996) "The Work Values and Job Satisfaction of Business Educators In Secondary School Systems and Community / Technical Colleges in Arkansas", Ph. D. Dissertation, Texas A\&M University, Texas.

George, J.M. ve Jones, G.R. (1997) "Experiencing Work: Values, Attitudes and Moods" Human Relations 50(4), s. 393416.

Jiang, X. ve Yang, J. (2011) “Understanding the Work Values of Chinese Employees” Psychology 2(6), s. 579-583.

Jurgensen, C.E. (1978), “Job Preferences: What Makes a Job Good or Bad?” Journal of Applied Psychology 63(3), s. 267-276.

Kasnak, E. (1998) “Çalışanların İş Değerleri ve Bir Özel Sektör Şirketinde Uygulama”, Yüksek Lisans Tezi, Hacettepe Üniversitesi, Ankara.

Kaya, B. (2010) "Öğretim Elemanlarının İş Değerleri Açısından Örgütsel Davranış Modellerinin İncelenmesi”, Yüksek Lisans Tezi, Eskişehir Osmangazi Üniversitesi, Eğitim Bilimleri Enstitüsü, Eskişehir.

Kline, R.B. (1998) Principal and Practice of Structural Equation Modeling, The Guilford Press, New York.

Konrad, A.M., Ritchie, J.E. Jr., Lieb, P. ve Corrigall, E. (2000) "Sex Differences and Similarities in Job Attribute Preferences: A Meta-Analysis" Psychological Bulletin 126, s. 593-641.

Kubat, U. ve Kuruüzüm, A. (2010) "İş Değerleri ve Kișilik Özellikleri Arasındaki İlişkinin İncelenmesi: Bir Yapısal Denklem Modelleme Yaklaşımı” Süleyman Demirel Üniversitesi İktisadi ve İdari Bilimler Fakültesi Dergisi 15(3), s. 487-505.

Kuvan, H. (2007) "Türk Girişimcilerin Yaşam ve Çalışma Değerleri: Malatyalı Girişimciler Üzerine Bir Araştırma", Yayınlanmamış Doktora Tezi, Süleyman Demirel Üniversitesi Sosyal Bilimler Enstitüsü, Isparta.

Li, W., Liu, X. ve Wan, W. (2008) "Demographic Effects of Work Values and Their Management Implications", Journal of Business Ethics 81, s. 875-885.

Örücü, E., Asunakutlu, T. ve Öncü, G. (2003) “Çalışanların İş Değerleri ve Bir Uygulama” İktisat İşletme ve Finans 18, s. 3-17.

Özkan, Ç. ve Gümüş, M. (2013) "Ege Bölgesindeki 4-5 Yıldızlı Otel İşletmelerinde Örgüt Kültürünün İş Değerlerinin Dönüşümüne Etkileri” KMÜ Sosyal ve Ekonomik Araştırmalar Dergisi 15(25), s. 1-14.

Pehlivan, A. (2012) "Öğretmen Adaylarının Anadolu Ağızlarına Yönelik Tutum Ölçeğinin Geçerlik ve Güvenirlik Çalışması” Bilig 63, s. 135-158.

Rowe, R. ve Snizek, W.E. (1995) "Gender Differences in Work Values: Perpetuating the Myth" Work and Occupations 22, s. 215-229.

Sagie, A., Elizur, D. ve Koslowsky, M. (1996) "Work Values: A Theoretical Overview and a Model of Their Effects" Journal of Organizational Behavior 17, s. 503-514. 
Scherer, R.F., Wiebe, F.A., Luther, D.C. ve Adams, J.S. (1988) "Dimensionality of Coping: Factor Stability Using The Ways of Coping Questionnaire" Psychological Reports 62(3), s. 763-770.

Selmer, J. ve Waldstrøm, C. (2007) "Work Values of Surviving and Non-Surviving Managers During Economic Recession" Career Development International 12(5), s. 433-445.

Sığrı, Ü. (2007) "Kamu ve Özel Sektördeki Kişisel ve Örgütsel Değerlerin Uyumlaştırılması Üzerine Karşılaştırmalı Bir Çalışma" Muğla Üniversitesi Sosyal Bilimler Enstitüsü Dergisi (İLKE) 18, s. 49-62.

Shapira, Z. ve Griffith, T.L. (1990) "Comparing the Work Values of Engineers With Managers, Production and Clerical Workers: A Multivariate Analysis” Journal of Organizational Behavior 11(4), s. 281-292.

Super, D.E. (1970) Work Values Inventory: Manual, Riverside Publishing Company, Chicago.

Tavşancıl, E. (2014) Tutumların Ölçülmesi ve SPSS ile Veri Analizi, Nobel Akademik Yayıncılık, Ankara.

Türkay, O. ve Akgöz, E. (2016) "Yaşam Değerleri ile İş Değerleri Arasındaki Etkileşim: Otel Çalışanları Örneği” Bartın Üniversitesi IIBF Dergisi 1(14), s. 147-164.

Uyan, G. (2002) “Öğretmenlerin İş Değerleri, Kişilik Özellikleri ve İş Tatminleri Arasındaki İlişkilerin İncelenmesi: MEB’na Bağlı Resmi ve Özel Eğitim Kurumlarında Gerçekleştirilen Bir Araştırma”, Yüksek Lisans Tezi, İstanbul Üniversitesi, İstanbul.

Wanous, J.P., Keon, T.L. ve Latack, J.C. (1983) "Expectancy Theory and Occupational/Organizational Choices: A Review and Test" Organizational Behavior and Human Performance 32(1), s. 66-86.

Weihrich, H. ve Koontz, H. (1993) Management, McGraw-Hill Book Company, New York.

Zytowski, D.G. (1994) “A Super Contribution to Vocational Theory: Work Values” The Career Development Quarterly 43(1), s. 25-31. 